\title{
8. CLAY MINERALOGY OF NEOGENE SEDIMENTS OF THE WESTERN ARABIAN SEA: MINERAL ABUNDANCES AND PALEOENVIRONMENTAL IMPLICATIONS ${ }^{1}$
}

\author{
P. Debrabant,$^{2}$ L. Krissek, ${ }^{3}$ A. Bouquillon, ${ }^{2}$ and H. Chamley ${ }^{2}$
}

\begin{abstract}
Clay mineral relative abundances in approximately 450 samples from cores recovered during ODP Leg 117 in the Arabian Sea have been used to examine the paleoclimatic, paleoenvironmental, and tectonic histories of the Indus Fan, Owen Ridge, Oman margin, and adjacent continental source regions. Geographic variations in the relative abundances of minerals and correlations with depositional processes support previous interpretations that smectite has been supplied from weathering of the Deccan Traps; illite and chlorite have been supplied either from the Himalayas via marine transport or from the Iran-Makran region by winds; and palygorskite has been supplied from the Arabian peninsula and Somalia by winds.

Pleistocene sediments of the Indus Fan record two modes of deposition: turbidites supplied from the Indus drainage and dominated by illite and chlorite, and pelagic carbonates containing smectites and wind-transported palygorskite. Local and regional causes for shifts between these depositional processes cannot be demonstrated conclusively with the data available, but sea-level fluctuations probably exerted a significant control on the rate of turbidite influx. Lower Miocene sediments on the Owen Ridge are also turbidites supplied by the Indus drainage; in the middle Miocene, a shift to pelagic carbonates records the uplift of the Owen Ridge, and is accompanied by the increased relative importance of wind-transported palygorskite. Associations of palygorskite and biosiliceous components in middle to upper Miocene sediments are interpreted to record vigorous monsoonal circulation and accompanying upwelling-produced biological productivity. Mineralogic and geochemical data indicate that light/dark color alternations in upper Miocene sediments on the Owen Ridge record climatic fluctuations, but the climatic significance of similar alternations in Pliocene-Pleistocene sediments is unclear. Palygorskite is the dominant clay on the Oman margin, reflecting proximity to its source areas. On the Oman margin, clay mineral relative abundances are most variable at structurally complex sites, indicating that local depositional settings have been influenced by their tectonic histories since the Miocene.
\end{abstract}

\section{INTRODUCTION}

Leg 117 of the Ocean Drilling Program was conducted in the Arabian Sea with several major objectives:

1. To investigate the uplift and erosion history of the TibetHimalayan complex and the effects of eustatic sea level fluctuations as recorded on the Indus Fan;

2. To investigate the tectonic history of the Owen Ridge, and to recover and investigate the high-resolution pelagic sediment sections deposited there under the influence of upwelling-driven surface productivity; and

3. To investigate the Cenozoic paleoclimatic and paleoenvironmental record preserved in rapidly accumulating, organicrich sediments on the Oman continental margin, especially focusing on the history of monsoon-driven upwelling.

Limited recovery of sediments on the Indus Fan precludes detailed examination of the histories of Tibetan Plateau/Himalayan uplift/erosion and eustatic sea-level fluctuations. Excellent sediment recovery at all other sites, however, provides material suitable for detailed studies of the Owen Ridge and the Oman margin. Within the limitations imposed by the recovered material, each of these objectives includes questions about the Cenozoic paleoclimate of the Arabian Sea region and the tectonic histories of the surrounding landmasses. General relation-

${ }^{1}$ Prell, W. L., Niitsuma, N., et al., 1991. Proc. ODP, Sci. Results, 117: College Station, TX (Ocean Drilling Program).

${ }^{2}$ Sedimentologie, URA694, Universite de Lille 1, 50655 Villeneuve d'Asco Cedex, France.

${ }^{3}$ Department of Geology and Mineralogy, Ohio State University, Columbus, OH 43210-1398, U.S.A. ships between the lithology and the weathering regimes of a source area and the composition of the clay mineral assemblage derived from that source area were established on a global scale by Griffin et al. (1968) and Lisitzin (1972). Numerous other studies have confirmed such relationships on basinwide (e.g., Biscaye, 1965) and local or regional scales. Chamley (1979) expanded this approach by including the effects of tectonic setting on the composition of the clays produced. As a result, the study of clay mineral assemblages in marine sediments is widely recognized for its contribution to paleoenvironmental interpretations of continental source areas (e.g., Chamley, 1989).

In addition to the global-scale studies mentioned previously, Kolla et al. $(1976 ; 1981)$ have conducted detailed studies of clay minerals in surface sediments of the western Indian Ocean and the Arabian Sea. On the basis of geographic patterns of clay mineral abundances, they concluded that:

1. Smectites are derived from the Deccan Traps of India;

2. Kaolinites in the northern Arabian Sea are probably derived from tropical soils of southern India;

3. Illite and chlorite are derived either from the Himalayan complex and supplied to the Indus Fan and adjacent areas by the Indus River, or from soils in the Iran-Makran region and supplied to the Gulf of Oman by northwest winds; and

4. Palygorskite (a fibrous clay) is derived from soils of the Arabian peninsula and Somalia, and supplied to the Arabian Sea by westerly and southwesterly winds. Although sepiolite was not reported by Kolla et al. $(1976 ; 1981)$, the similarity of conditions favoring palygorskite and sepiolite formation indicates that these sources may also provide sepiolite to the Arabian Sea.

These compositionally distinctive source area signatures provide the basis for this study, which outlines variations in the en- 
vironmental characteristics and relative importance of the various sources to the Arabian Sea since the Miocene. In doing so, the paleoclimatic and paleoenvironmental histories of the Arabian Sea and the surrounding continents are identified, and the tectonic history of the Owen Ridge is examined.

\section{MATERIAL AND METHODS}

For this study, the clay mineralogy of approximately 450 samples was analyzed; these samples were obtained from nine sites grouped in three physiographic settings: Site 720 on the Indus Fan, Sites 721,722 , and 731 on the Owen Ridge, and Sites $723,725,726,728$, and 730 on the Oman margin (Fig. 1, Table 1). On average, two samples were taken per core in appropriate lithologies at Site 721. An average of one sample per core was taken in appropriate lithologies at all other sites. These sample spacings represent sampling intervals of approximately 0.02 to $0.1 \mathrm{~m} . \mathrm{y}$. on the Indus Fan, approximately 0.5 to $1.0 \mathrm{~m} . \mathrm{y}$. on the Owen Ridge, and approximately 0.05 to $1.0 \mathrm{~m} . \mathrm{y}$. on the Oman margin (Prell, Niitsuma, et al., 1989); more accurate age control is not available at this time.

The clay mineral data were obtained by analyzing the $<2 \mu \mathrm{m}$ size fraction by $\mathrm{x}$-ray diffraction (XRD). Samples were pretreated with $5 \mathrm{~N} \mathrm{HCl}$ to remove carbonates, and the $<2 \mu \mathrm{m}$ fraction was extracted by settling and decantation. The $<2 \mu \mathrm{m}$ materials were then prepared as oriented mounts on glass slides, and each was scanned three times: from $2.5^{\circ}$ to $28.5^{\circ} 2 \theta$ on unexpanded and unheated samples, from $2.5^{\circ}$ to $14.5^{\circ} 2 \theta$ on glycolated samples, and from $2.5^{\circ}$ to $14.5^{\circ} 2 \theta$ on samples heated for $2 \mathrm{hr}$ at $490^{\circ} \mathrm{C}$. The analytical techniques and the methods of quantitatively interpreting the diffractograms are described in detail in Chamley and Debrabant (1984) and Holtzapffel (1985). Analytical uncertainties in the clay mineral relative abundances are estimated to be $\pm 5 \%$ (absolute) for abundances above $20 \%$, \pm $3 \%$ (absolute) for abundances between $5 \%$ and $20 \%$, and \pm $2 \%$ (absolute) for abundances less than $5 \%$.

The diffractograms also indicate the presence of a variety of non-phyllosilicate minerals (quartz, feldspar, amphibole, orthopyroxene, gibbsite, goethite, serpentine, zeolites), whose abundances cannot be quantified with this analytical technique. As a result, these minerals are described as "present," "common," "abundant," or "very abundant" on the basis of the relative size of their characteristic peaks on the diffractograms. Estimated abundances of some of these minerals in the bulk sediment are available from the shipboard smear slide data (Prell, Niitsuma, et al., 1989). Other analyses were conducted on selected samples, and include XRD analysis of the bulk sediment, spectrochemical analysis (see Chamley and Debrabant (1984) for the analytical procedure), organic carbon and sulfur determination (using a LECO induction furnace), and transmission electron microscopy.

All values reported here are relative clay mineral abundances (i.e., abundance of that clay mineral relative to the total clay mineral assemblage in that sample). Some ambiguities arise when interpreting this type of data because the relative abundance of a mineral can be changed either by changing its input rate or by changing the input rate of another mineral or minerals (i.e., a "dilution" effect). Although presenting the data as mass accumulation rates (MAR's) for each mineral would overcome this ambiguity, we have chosen not to use MAR's for the following reasons:

1. Total sediment MAR's are not available for all of the stratigraphic intervals examined here, especially some of the intervals where relative clay mineral abundances change significantly; and

2. Variations in the abundance of terrigenous clay relative to the total sediment are poorly constrained throughout the inter-
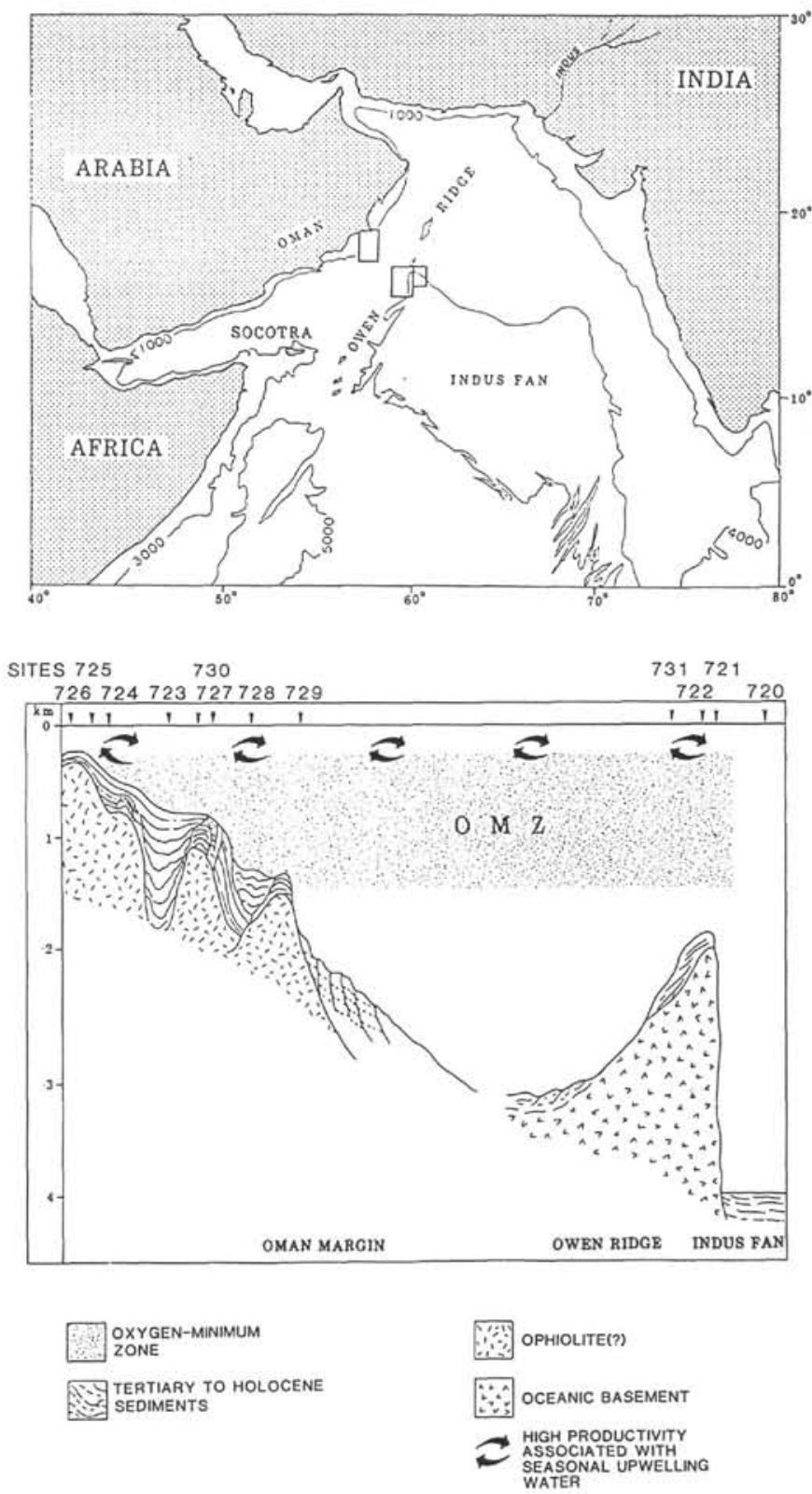

Figure 1. Location map and bathymetric profile of sites drilled during ODP Leg 117. Site 720 is located on the western distal Indus Fan; Sites 721,722 , and 731 are located on the Owen Ridge; Sites 723 through 730 are located on the Oman margin. The bathymetric profile also shows the position of the modern oxygen minimum zone (OMZ) and the extent of monsoon-driven upwelling and high productivity in the surface waters (arrows).

vals studied. Without these data, it is impossible to accurately calculate MAR's for individual minerals within the clay fraction.

Paleoenvironmental interpretations of the clay mineral assemblages are based on the general associations outlined previously between lithology and weathering regime of a source and the clays derived from that source. Additional paleoenvironmental information has been provided by calculating three ratios of mineral relative abundances: 
Table 1. Locations and characteristics of sites drilled during Leg 117.

\begin{tabular}{lccccc}
\hline Site & $\begin{array}{c}\text { Latitude } \\
(\mathrm{N})\end{array}$ & $\begin{array}{c}\text { Longitude } \\
(\mathrm{E})\end{array}$ & $\begin{array}{c}\text { Water } \\
\text { depth } \\
(\mathrm{m})\end{array}$ & $\begin{array}{c}\text { Maximum } \\
\text { penetration } \\
(\mathrm{mbsf})\end{array}$ & Setting \\
\hline 720 & $16^{\circ} 08^{\prime}$ & $60^{\circ} 45^{\prime}$ & 4038 & 414.3 & Indus Fan \\
721 & $16^{\circ} 41^{\prime}$ & $59^{\circ} 52^{\prime}$ & 1945 & 424.2 & Owen Ridge \\
722 & $16^{\circ} 37^{\prime}$ & $59^{\circ} 48^{\prime}$ & 2028 & 565.0 & Owen Ridge \\
723 & $18^{\circ} 03^{\prime}$ & $57^{\circ} 86^{\prime}$ & 808 & 423.2 & Oman Margin \\
725 & $18^{\circ} 29^{\prime}$ & $57^{\circ} 42^{\prime}$ & 312 & 162.8 & Oman Margin \\
726 & $17^{\circ} 49^{\prime}$ & $57^{\circ} 22^{\prime}$ & 332 & 186.3 & Oman Margin \\
728 & $17^{\circ} 41^{\prime}$ & $59^{\circ} 50^{\prime}$ & 1428 & 346.8 & Oman Margin \\
730 & $17^{\circ} 39^{\prime}$ & $57^{\circ} 42^{\prime}$ & 1066 & 403.9 & Oman Margin \\
731 & $16^{\circ} 28^{\prime}$ & $59^{\circ} 42^{\prime}$ & 2366 & 994.0 & Owen Ridge \\
\hline
\end{tabular}

1. Kaolinite/chlorite, which indicates the relative importance of chemical to physical weathering processes in the sediment sources;

2. Smectite/kaolinite, which indicates the relative importance of upland (rapidly eroded) to lowland (heavily leached and slowly eroded) sources; and

3. Smectite/palygorskite, which indicates the relative importance of eastern and northern to western source regions.

\section{CLAY MINERALOGY OF INDUS FAN SEDIMENTS}

Site 720 was the only site drilled on the Indus Fan during ODP Leg 117. The Quaternary sedimentary record at Site 720 is dominated by turbidites composed of interbedded silty clays, silts, silty sands, and sands. These sediments form the bulk of lithologic Unit II, which extends from 17.2 to $414.3 \mathrm{mbsf}$, but are interrupted by thin pelagic intervals composed of nannofossil ooze and foraminifer-bearing nannofossil ooze (Fig. 2; Prell,

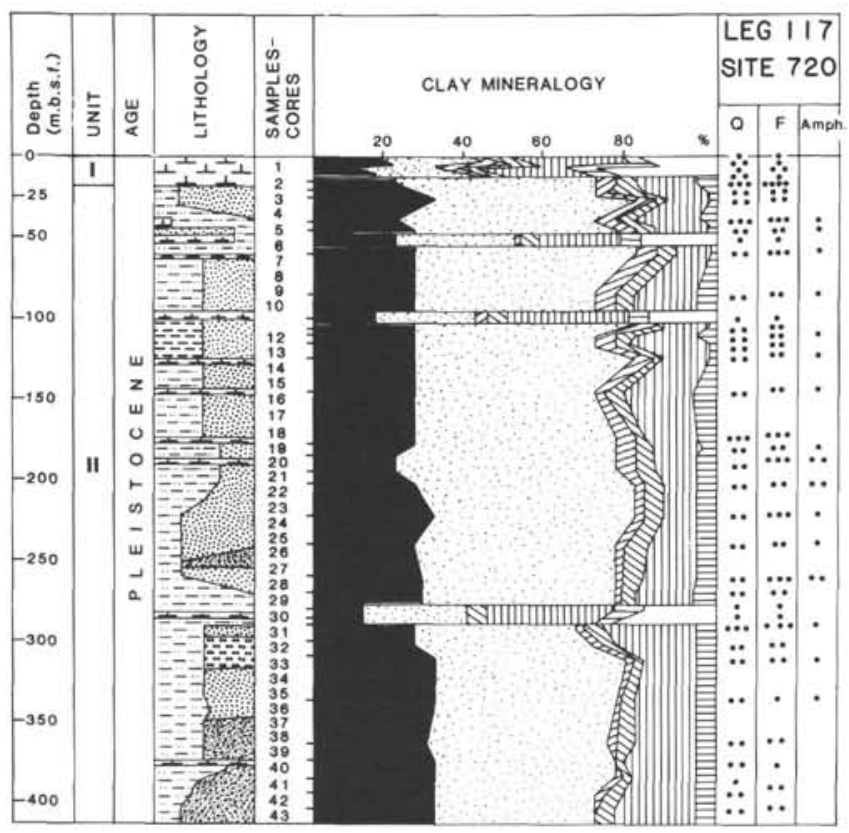

Figure 2. Clay mineral abundances at Site 720 on the distal western Indus Fan. The majority of the section is composed of turbidites containing abundant chlorite and illite; the thin zones that contain palygorskite are pelagic carbonates. Carbonate intervals at 60, 125, 145, 175, 185, and 370 mbsf were not sampled, and are only known to exist from downhole logging data. "Q," "F," and "Amph." columns indicate relative abundances of quartz, feldspars, and amphiboles, respectively (more dots indicate greater relative abundance).
CLAY MINERALOGY

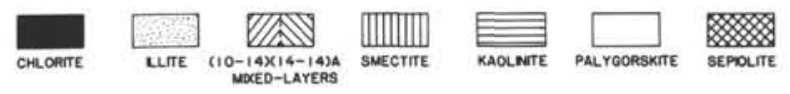

LITHOLOGY

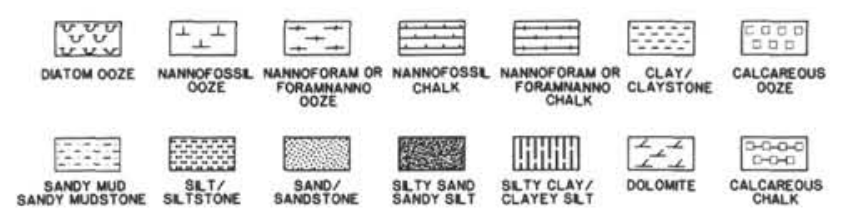

Figure 2 (continued).

Niitsuma, et al., 1989). Lithologic Unit I extends from the mud line to $17.2 \mathrm{mbsf}$, and is composed of nannofossil ooze and foraminifer-bearing nannofossil ooze similar to that of the pelagic intervals in Unit II. Thirty-nine samples from Site 720 were analyzed, with an average sampling interval of approximately $10 \mathrm{~m}$. Because recovery at Site 720 was poor, these samples are distributed irregularly through the sedimentary section (Fig. 2), and not all of the pelagic intervals in lithologic Unit II were sampled. In particular, the carbonate intervals at approximately 60 , $125,145,175,185$, and 370 mbsf were not sampled.

The mineralogic data for Site 720 are plotted downcore in Figure 2, and the average relative abundance and standard deviation for each mineral in each lithologic unit are tabulated in Table 2. These data clearly distinguish the turbidites from the pelagic deposits that were sampled. The clay mineral assemblage in the silty and sandy turbidites of the Indus Fan is dominated by illites and chlorites, which average approximately $74 \%$ of the clay fraction. The total relative abundance of irregular mixed-layer clays (predominantly illite-smectite $10-14 \AA$ and chlorite-smectite 14-14 $\AA$ ), smectites, and kaolinites does not exceed $40 \%$ in any sample analyzed (Fig. 2). Quartz and feldspars are abundant to very abundant in the turbidite intervals, with up to $80 \%$ quartz and $20 \%$ feldspar reported from shipboard smear slide analyses (Prell, Niitsuma, et al., 1989).

The composition of suspended material in the Indus River (Konta, 1985) and the clay mineralogy of surface sediments of the proximal Indus Fan (Kolla et al., 1976) identify the western part of the Himalayas as the most important source of illite and chlorite, whereas the Deccan Traps region of the Indian subcontinent supplies abundant smectites. These sources supply the clay minerals identified at Site 720. Clay mineral relative abundances show no consistent trends or large amplitude variations through the turbidite intervals of Unit II. Zones of increased compositional variability at Site 720 are generally located at intervals of enhanced recovery, suggesting that the observation of compositional variability is at least partly controlled by sampling density. Within the limits of the recovered section, however, the variations are of small amplitude and short duration, suggesting that they reflect limited fluctuations in sediment supply. Such fluctuations could be generated by climatic changes in the Indus River basin, or by diversion of fluvial or submarine fan distributary channels. The limited scale of the compositional changes does not support longer-term tectonic events as their cause.

The biocalcareous oozes at Site 720 , which comprise lithologic Unit I and the pelagic intervals in lithologic Unit II, contain relatively more smectite and palygorskite than the turbidite intervals (Table 2; Pl. 1). These pelagic intervals were deposited during times when the relative importance of turbidity current activity decreased at this location. In this type of setting on a submarine fan, turbidity flow input can change because of local 
Table 2. Summary (mean/standard deviation) of mineral relative abundances, calculated for each lithologic unit/subunit at each site."

\begin{tabular}{|c|c|c|c|c|c|c|c|c|c|}
\hline Site & Unit & $\mathrm{N}$ & $\begin{array}{c}\text { Chlorite } \\
(\%)\end{array}$ & $\begin{array}{l}\text { Illite } \\
(\%)\end{array}$ & $\begin{array}{c}10-14 \mathrm{ML} \\
(\%)\end{array}$ & $\begin{array}{c}14-14 \mathrm{ML} \\
(\%)\end{array}$ & $\begin{array}{c}\text { Smectite } \\
(\%)\end{array}$ & $\begin{array}{c}\text { Kaolinite } \\
(\%)\end{array}$ & $\begin{array}{c}\text { Palygorskite }+ \\
\text { Sepiolite } \\
(\%)\end{array}$ \\
\hline \multirow[t]{3}{*}{720} & I & 4 & $15 / 4$ & $25 / 4$ & $2 / 2$ & $5 / 2$ & $26 / 3$ & $5 / 2$ & $24 / 9$ \\
\hline & $\begin{array}{l}\text { II } \\
\text { (turbidite }\end{array}$ & s) & $26 / 3$ & $48 / 5$ & $3 / 2$ & $4 / 2$ & $16 / 4$ & $4 / 2$ & $0 / 0$ \\
\hline & $\begin{array}{l}\text { II } \\
\text { (carbona }\end{array}$ & $\begin{array}{l}4 \\
\text { (tes) }\end{array}$ & $15 / 4$ & $26 / 3$ & $0 / 0$ & $5 / 2$ & $28 / 6$ & $5 / 2$ & $21 / 4$ \\
\hline \multirow[t]{5}{*}{721} & IA & 55 & $8 / 3$ & $15 / 3$ & $7 / 2$ & $10 / 3$ & $26 / 7$ & $7 / 2$ & $27 / 6$ \\
\hline & IB & 4 & $6 / 3$ & $15 / 3$ & $6 / 3$ & $8 / 3$ & $30 / 4$ & $5 / 2$ & $30 / 2$ \\
\hline & II & 4 & $3 / 2$ & $10 / 3$ & $10 / 4$ & $6 / 3$ & $29 / 11$ & $5 / 2$ & $35 / 12$ \\
\hline & III & 6 & $8 / 3$ & $13 / 3$ & $11 / 4$ & $7 / 3$ & $29 / 9$ & $7 / 3$ & $26 / 9$ \\
\hline & IV & 11 & $24 / 6$ & $28 / 6$ & $6 / 2$ & $6 / 2$ & $26 / 8$ & $4 / 4$ & $7 / 7$ \\
\hline \multirow[t]{4}{*}{722} & I & 23 & $10 / 3$ & $19 / 4$ & $6 / 2$ & $11 / 4$ & $28 / 7$ & $10 / 2$ & $16 / 6$ \\
\hline & II & 11 & $9 / 2$ & $15 / 4$ & $5 / 2$ & $10 / 2$ & $30 / 4$ & $5 / 2$ & $24 / 7$ \\
\hline & III & 7 & $12 / 6$ & $18 / 6$ & $5 / 2$ & $6 / 2$ & $34 / 11$ & $6 / 3$ & $17 / 5$ \\
\hline & IV & 14 & $26 / 7$ & $29 / 6$ & $5 / 2$ & $5 / 2$ & $29 / 12$ & $4 / 2$ & $2 / 2$ \\
\hline 723 & I & 24 & $9 / 3$ & $17 / 3$ & $4 / 2$ & $19 / 4$ & $11 / 3$ & $3 / 2$ & $40 / 4$ \\
\hline \multirow[t]{3}{*}{725} & I & 23 & $10 / 3$ & $16 / 2$ & $2 / 2$ & $9 / 3$ & $13 / 4$ & $4 / 2$ & $47 / 5$ \\
\hline & II & 3 & $7 / 3$ & $12 / 3$ & $7 / 3$ & $17 / 3$ & $8 / 3$ & $2 / 2$ & $43 / 3$ \\
\hline & III & 1 & $5 / 0$ & $15 / 0$ & $10 / 0$ & $5 / 0$ & $10 / 0$ & $2 / 0$ & $40 / 0$ \\
\hline \multirow[t]{2}{*}{726} & IA & 4 & $13 / 3$ & $15 / 2$ & $2 / 2$ & $9 / 5$ & $11 / 3$ & $6 / 3$ & $43 / 7$ \\
\hline & IB & 6 & $11 / 2$ & $15 / 2$ & $5 / 2$ & $10 / 6$ & $13 / 10$ & $4 / 2$ & $45 / 20$ \\
\hline \multirow[t]{3}{*}{728} & IA & 6 & $13 / 3$ & $19 /$ & $4 / 2$ & $11 / 4$ & $13 / 9$ & $5 / 2$ & $35 / 4$ \\
\hline & IB & 27 & $8 / 3$ & $16 / 2$ & $5 / 3$ & $16 / 5$ & $16 / 6$ & $5 / 2$ & $36 / 4$ \\
\hline & IC & 3 & $10 / 2$ & $17 / 3$ & $2 / 2$ & $17 / 3$ & $22 / 3$ & $2 / 2$ & $35 / 5$ \\
\hline \multirow[t]{7}{*}{730} & I & 2 & $13 / 4$ & $15 / 2$ & $7 / 3$ & $10 / 2$ & $18 / 3$ & $5 / 2$ & $35 / 7$ \\
\hline & IIA & 2 & $10 / 2$ & $15 / 2$ & $7 / 3$ & $8 / 3$ & $20 / 7$ & $5 / 2$ & $35 / 7$ \\
\hline & IIB & 8 & $7 / 3$ & $12 / 3$ & $10 / 4$ & $14 / 4$ & $23 / 6$ & $4 / 2$ & $29 / 6$ \\
\hline & IIC & 5 & $5 / 2$ & $11 / 2$ & $7 / 3$ & $11 / 7$ & $31 / 11$ & $5 / 2$ & $27 / 3$ \\
\hline & IIIA & 7 & $6 / 2$ & $12 / 3$ & $6 / 2$ & $11 / 5$ & $31 / 4$ & $5 / 2$ & $28 / 4$ \\
\hline & IIIB & 6 & $6 / 2$ & $13 / 3$ & $5 / 2$ & $9 / 4$ & $28 / 8$ & $2 / 2$ & $37 / 4$ \\
\hline & IIIC & 5 & $5 / 2$ & $12 / 3$ & $5 / 2$ & $10 / 4$ & $31 / 4$ & $2 / 2$ & $37 / 4$ \\
\hline \multirow[t]{7}{*}{731} & IA & 7 & $9 / 2$ & $18 / 5$ & $5 / 2$ & $10 / 3$ & $19 / 3$ & $9 / 2$ & $24 / 12$ \\
\hline & IB & 7 & $9 / 2$ & $13 / 4$ & $5 / 2$ & $13 / 3$ & $26 / 4$ & $7 / 3$ & $26 / 6$ \\
\hline & II & 3 & $5 / 2$ & $12 / 3$ & $5 / 2$ & $13 / 3$ & $28 / 15$ & $7 / 3$ & $28 / 16$ \\
\hline & ${ }_{26 \mathrm{X}}-32 \mathrm{X}$ & 7 & $8 / 4$ & $14 / 7$ & $5 / 2$ & $9 / 4$ & $26 / 7$ & $6 / 2$ & $33 / 10$ \\
\hline & $\underset{\text { IV }}{33 X-34 X}$ & 2 & $30 / 5$ & $38 / 4$ & $5 / 2$ & $8 / 4$ & $15 / 3$ & $5 / 2$ & $2 / 2$ \\
\hline & $35 \mathrm{X}-6 \mathrm{R}$ & 26 & $25 / 5$ & $32 / 5$ & $5 / 2$ & $7 / 2$ & $24 / 7$ & $5 / 2$ & $2 / 2$ \\
\hline & $7 \mathrm{~W}-24 \mathrm{R}$ & 24 & $18 / 3$ & $28 / 4$ & $5 / 2$ & $10 / 2$ & $29 / 6$ & $9 / 2$ & $0 / 0$ \\
\hline
\end{tabular}

${ }^{\mathrm{a}} \mathrm{N}=$ number of samples; $10-14 \mathrm{ML}=10-14 \AA$ mixed-layer clays; $14-14 \mathrm{ML}=14-14 \AA$ mixed-layer clays.

(channel migration/switching) or regional (source changes caused by climatic or tectonic variations, or sea-level changes) controls. The clay mineral ratios of the turbidites and biocalcareous oozes provide some insight into the possible cause of this change in sediment input (Table 3). The kaolinite/chlorite and smectite/ kaolinite ratios do not change significantly with the change in depositional process, indicating that the relative importance of physical weathering, chemical weathering, upland sources, and lowland sources remained approximately constant. This uniformity suggests that neither large-scale tectonic events nor major climatic changes in the continental source areas were responsible for the shifts between turbidite and carbonate deposition. The smectite/palygorskite ratio does change significantly, however, indicating that the western source was relatively important only during times of carbonate deposition. In order for carbonate deposition to occur, turbidity flow input was reduced, which removed the major dilutant of palygorskite contributed by eolian processes. The input of turbidity currents may have been decreased by channel switching, or by a rise in eustatic sea level, which trapped the Indus discharge in nearshore environments. A detailed correlation of the Site 720 record to published eustatic sea-level curves would clarify the effect of sea-level fluctuations on deposition at Site 720 , but such a correlation is precluded by the poor recovery and limited biostratigraphic control at this site.

\section{CLAY MINERALOGY OF OWEN RIDGE SEDIMENTS}

Sites 721, 722, and 731 are from the Owen Ridge (Fig. 1), and have similar sedimentary sections of early Miocene to late Pleistocene/Holocene age. Lithologic Unit I at each site consists of alternating light and dark layers of foraminifer-bearing nannofossil ooze to foraminifer-nannofossil ooze, and nannofossil ooze of Holocene/late Pleistocene to late Miocene age. Radiolarian and foraminiferal assemblages indicative of upwelling occur throughout this interval, and a variety of 12 compositional and physical properties show a strongly cyclic pattern of variation (Prell, Niitsuma, et al., 1989). Lithologic Unit II at each site is middle Miocene to late Miocene in age, and is distinguished from Unit I by the presence of biogenic opal. Unit III is dominated by nannofossil chalks and marly nannofossil chalks of early to middle Miocene age, whereas Unit IV at each site contains sandy to muddy turbidites of early to middle Miocene age. A transitional interval of muddy turbidites with calcareous pelagic caps occurs at each site, and is placed at the top of Unit IV in each case. The change from turbidite to pelagic carbonate deposition is interpreted to record uplift of the Owen Ridge above the level of active deposition on the Indus Fan in the early to middle Miocene (Prell, Niitsuma, et al., 1989). Clays supplied by eolian and pelagic processes since that time were not di- 
Table 3. Average mineral ratios for each lithologic unit/subunit at each site. ${ }^{\mathrm{a}}$

\begin{tabular}{|c|c|c|c|c|}
\hline Site & Unit & $\mathrm{Kaol} / \mathrm{Chl}$ & Smec/Kaol & Smec/Palyg \\
\hline \multirow[t]{3}{*}{720} & I & 0.3 & 5.2 & 1.1 \\
\hline & $\begin{array}{l}\text { II } \\
\text { (turbidites) }\end{array}$ & 0.2 & 4.0 & - \\
\hline & $\begin{array}{l}\text { II } \\
\text { (carbonates) }\end{array}$ & 0.3 & 5.6 & 1.3 \\
\hline \multirow[t]{5}{*}{721} & IA & 0.9 & 3.7 & 1.0 \\
\hline & IB & 0.8 & 6.0 & 1.0 \\
\hline & II & 1.7 & 5.8 & 0.8 \\
\hline & III & 0.9 & 4.1 & 1.1 \\
\hline & IV & 0.2 & 6.5 & 3.7 \\
\hline \multirow[t]{4}{*}{722} & I & 1.0 & 2.8 & 1.8 \\
\hline & II & 0.6 & 6.0 & 1.2 \\
\hline & III & 0.5 & 5.7 & 2.0 \\
\hline & IV & 0.2 & 7.2 & 14.5 \\
\hline 723 & I & 0.3 & 3.7 & 0.3 \\
\hline \multirow[t]{3}{*}{725} & I & 0.4 & 3.2 & 0.3 \\
\hline & II & 0.3 & 4.0 & 0.2 \\
\hline & III & 0.4 & 5.0 & 0.2 \\
\hline \multirow{2}{*}{726} & IA & 0.5 & 1.8 & 0.3 \\
\hline & IB & 0.4 & 3.2 & 0.3 \\
\hline \multirow[t]{3}{*}{728} & IA & 0.4 & 2.6 & 0.4 \\
\hline & IB & 0.6 & 3.2 & 0.4 \\
\hline & IC & 0.2 & 11.0 & 0.6 \\
\hline \multirow[t]{7}{*}{730} & I & 0.4 & 3.6 & 0.5 \\
\hline & IIA & 0.5 & 4.0 & 0.6 \\
\hline & IIB & 0.6 & 5.8 & 0.8 \\
\hline & IIC & 1.0 & 6.2 & 1.2 \\
\hline & IIIA & 0.8 & 6.2 & 1.1 \\
\hline & IIIB & 0.3 & 14.0 & 0.7 \\
\hline & IIIC & 0.4 & 15.5 & 0.8 \\
\hline \multirow[t]{8}{*}{731} & IA & 1.0 & 2.1 & 0.8 \\
\hline & IB & 0.8 & 3.7 & 1.0 \\
\hline & II & 1.4 & 4.0 & 1.0 \\
\hline & III & & & \\
\hline & $26 \mathrm{X}-32 \mathrm{X}$ & 0.8 & 4.3 & 0.8 \\
\hline & $\begin{array}{l}33 X-34 X \\
\text { IV }\end{array}$ & 0.2 & 3.0 & 7.5 \\
\hline & $35 \mathrm{X}-6 \mathrm{R}$ & 0.2 & 4.8 & 12.0 \\
\hline & $7 \mathrm{~W}-24 \mathrm{R}$ & 0.5 & 3.2 & - \\
\hline
\end{tabular}

${ }^{\mathrm{a}} \mathrm{Kaol} / \mathrm{Chl}=$ kaolinite/chlorite ratio; $\mathrm{Smec} / \mathrm{Kaol}=$ smectite/kaolinite ratio; Smec/Palyg = smectite/palygorskite ratio; "-" indicates no value.

luted by turbidite input, and provide a record of their sources. As a result, the sections recovered from the Owen Ridge have been used to address two questions: (1) the timing and nature of Owen Ridge uplift, and (2) the record of climatic fluctuations since the Owen Ridge was uplifted.

\section{Turbidites of the Owen Ridge}

Clay mineral relative abundances at Sites 721, 722, and 731, which are displayed stratigraphically in Figure 3 and listed in Table 2 , are very similar in the equivalent lithologic units at each site. Lithologic Unit IV at each site is dominated by illite, chlorite, and smectite, which together average approximately $75 \%$ of the clays. Relative abundances of chlorite are approximately equal in the Owen Ridge and Indus Fan turbidites, whereas the relative abundance of illite decreases from Site 720 to the Owen Ridge. Smectites have slightly higher average relative abundances in the Owen Ridge turbidites than on the Indus Fan (Table 2), and are significantly enriched in the more calcareous levels of the transitional turbidite/carbonate lithofacies, where smectite relative abundances reach 50\%-60\%. Kaolinite relative abundances are low (less than 10\%) in lithologic Unit IV, and decrease slightly upsection in the long record at Site 731 (Fig. 3; Table 2). Quartz and feldspars are abundant to very abundant throughout the unit, with abundance ranges of 5\%-65\% and $2 \%-10 \%$, respectively, estimated from smear slides of the bulk sediment (Prell, Niitsuma, et al., 1989). Palygorskite and gibbs- ite are preferentially present in the tops of turbidites and in the transitional carbonate/turbidite lithofacies.

In a general sense, Miocene turbidites on the Owen Ridge are mineralogically similar to Pleistocene turbidites on the Indus Fan. This suggests that similar sediment sources were active throughout this time, and supplied material to the vicinity of the Owen Ridge prior to its uplift above the level of active turbidity flows. The relative importance of input from each source may have changed through time, however. The major compositional differences between these two sample sets are the lower average relative abundance of illite and the episodic increases in smectite relative abundances in the Owen Ridge turbidites. These differences may reflect either the lateral migration of a major distributary channel away from this site, thereby increasing the relative input of the finer-grained smectites to a more distal setting, the episodic input of smectite from an African or Arabian source, or a relative decrease in the rate of supply from the Himalayan source, thereby reducing the supply of illite relative to smectite.

As discussed previously for Site 720 , short-duration changes in the rate and/or composition of the Indus contribution were most likely caused either by changes in eustatic sea level or by changes in climatic/weathering conditions in the continental source. The kaolinite/chlorite and smectite/kaolinite ratios (Table 3) for the turbidites at Sites 721 and 722 and the upper $300 \mathrm{~m}$ of Unit IV at Site 731 (325-625 mbsf) are relatively uniform, suggesting approximately similar influences of chemical vs. physical weathering and upland vs. lowland sources throughout their time of deposition. As a result, eustatic sea-level fluctuations are left as the potential dominant control on supply from the Indus drainage during the deposition of lower to middle Miocene turbidites presently found on the Owen Ridge. The mineral ratios do change in the deeper part of Unit IV at Site 731 (below $625 \mathrm{mbsf}$ ), suggesting that changes in weathering conditions and source area relief may have combined with sea-level fluctuations to control the Indus supply to the older turbidites.

The transition from lithologic Unit IV to lithologic Unit III at each site on the Owen Ridge occurs in lower to middle Miocene sediments. This transition is marked, in each case, by a significant increase in the importance of palygorskite relative to chlorite and illite (Fig. 3; Table 2; Pl. 1). Increased palygorskite relative abundances are characteristic of the pelagic intervals at Site 720; a similar association occurs in the Owen Ridge sites, where palygorskite relative abundances increased as uplift of the ridge moved the depositional sites above the level of turbidity flow input of illite and chlorite.

\section{Paleoenvironmental Records From The Owen Ridge}

Following uplift of the Owen Ridge sites above the level of turbidity flow influence, these areas received clay minerals transported predominantly by eolian processes and oceanic circulation. As a result, this setting is one of the best available in the northern Indian Ocean to observe the onset and behavior of the monsoonal circulation pattern; such climatic records are masked on the adjacent deep sea fans, where the Miocene was a time of rapid turbidite deposition in response to eustatic sea-level changes and major orogenic events in the Himalayan sources (Gansser, 1966).

Above the lithologic Unit III/IV boundary at each site on the Owen Ridge, the clay mineral assemblages generally contain less than $40 \%$ illite plus chlorite, $10 \%-20 \%$ mixed-layer clays, $15 \%-30 \%$ smectite, less than $10 \%$ kaolinite, and $15 \%-40 \%$ palygorskite (Fig. 3; Table 2). The kaolinite/chlorite relative abundance ratios (Table 3) exhibit no consistent stratigraphic pattern in the Owen Ridge sites, suggesting a complex history of chemical weathering vs. physical weathering effects in the sediment source areas. Smectite/kaolinite values generally decrease 


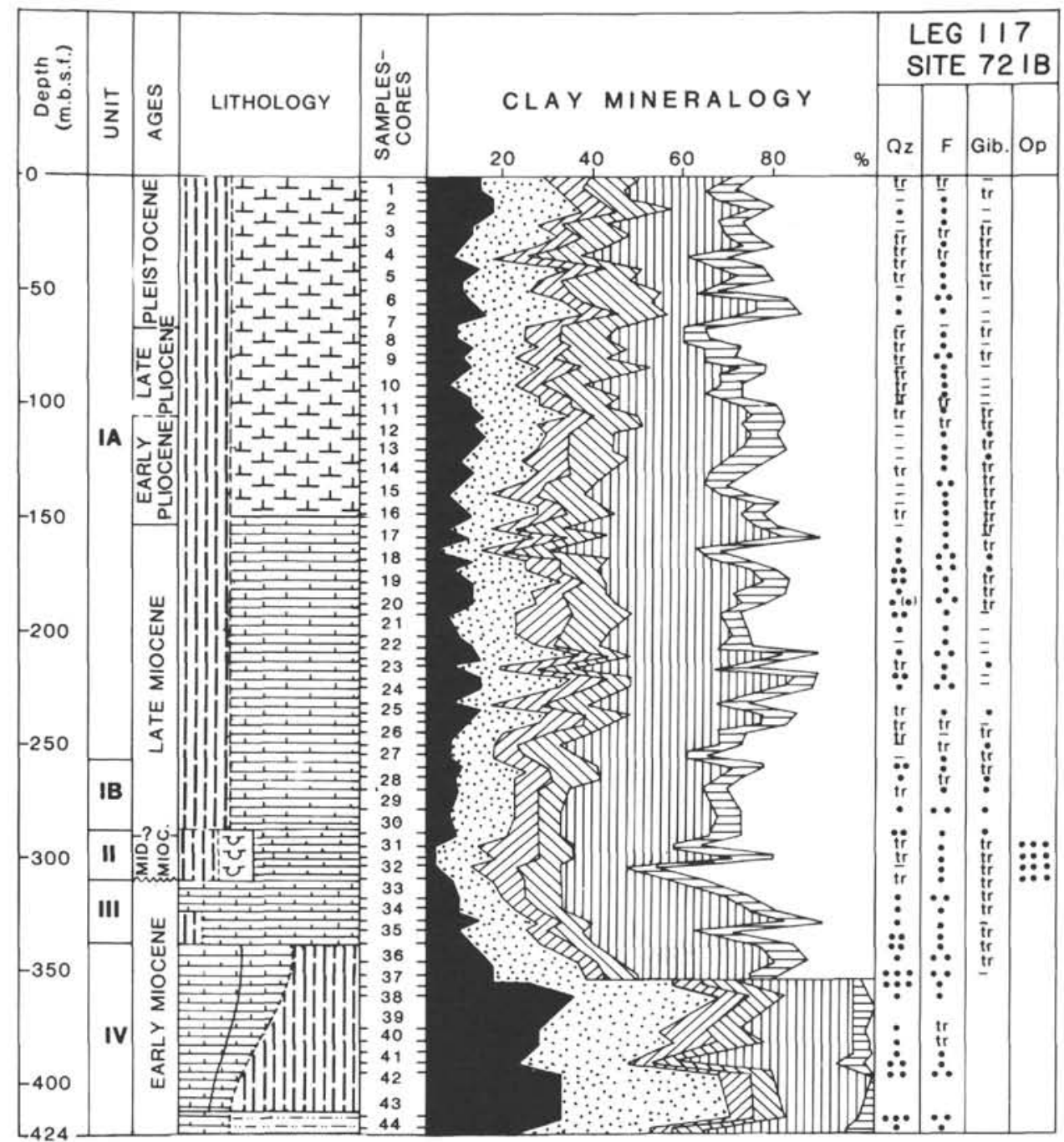

Figure 3. Clay mineral abundances at Sites 721, 722, and 731 on the Owen Ridge. "Qz," "F," "Gib.," and "Op" columns indicate relative abundances of quartz, feldspars, gibbsite, and orthopyroxene, respectively ("tr" indicates trace amounts; more dots indicate greater relative abundance). Lithologic symbols same as in Figure 2.

upsection, suggesting that the relative importance of contributions from lowland source areas increased through time. Smectite/palygorskite values are more variable, but have minima in lithologic Unit II at Sites 721 and 722 , indicating that the relative importance of wind-transported material from a western source was greatest during deposition in middle to late Miocene time.

The highest average relative abundances of palygorskite are generally found in lithologic Unit II, where well-preserved biosiliceous components are observed. Prell (1984) concluded that upwelling events, which increase biosiliceous productivity in the Arabian Sea, occur during the summer monsoon, when southwest winds are dominant. Weser (1974) indicated that palygorskite in Arabian Sea sediments was derived from source areas to the west and southwest, so the co-occurrence of high relative palygorskite abundances and biosiliceous components in lithologic Unit II at the Owen Ridge sites appears to record the onset of monsoonal circulation during the middle-to-late Miocene.

Within the pelagic biocalcareous sections at the Owen Ridge sites, variations in clay mineral relative abundances appear to follow the decimeter- to meter-scale cyclicity in color and other physical and compositional properties observed in the sedimen- tary section (Prell, Niitsuma, et al., 1989). In order to examine the general compositional variations of the light/dark color cycles, 30 samples, taken from 15 pairs of adjacent light and dark layers at Sites 721 and 722 , have been analyzed. A preliminary discussion of these data was presented by Bouquillon et al. (1988), but the data are described and documented more completely here. Compositional data for these samples are tabulated in the Appendix, and indicate the following differences: (1) the dark layers contain more silty nonbiogenic components, especially quartz and feldspar, than the light layers as shown by the $\mathrm{SiO}_{2} / \mathrm{Al}_{2} \mathrm{O}_{3}$ ratios and smear slide data (Prell, Niitsuma, et al., 1989); (2) the dark layers contain 5\%-10\% more palygorskite than the light layers; (3) the dark layers contain less calcium carbonate than the light layers; (4) the dark layers contain more organic carbon and sulfur than the light layers; and (5) the dark layers contain more siliceous microfossils than the light layers.

These compositional differences provide several internally consistent lines of evidence about the importance and characteristics of monsoonal circulation from the late Miocene to the Recent. First, palygorskites are fibrous clays, characteristically formed in saline and alkaline subaqueous settings in the Arabian and east African deserts (Millot, 1964; Weser, 1974; Kolla 


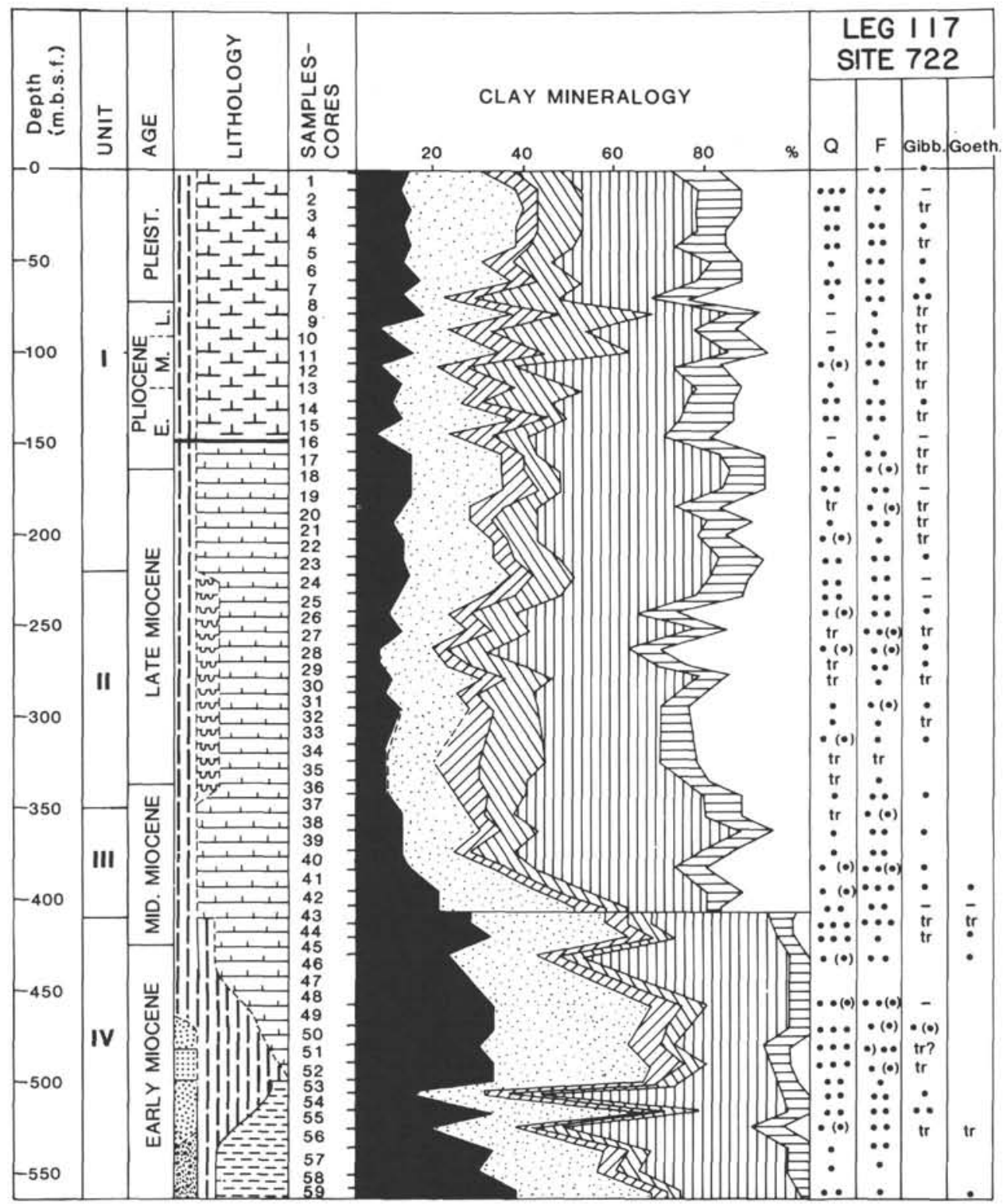

Figure 3 (continued).

et al., 1976; Caulet et al., 1988), and supplied to depositional sites in the open ocean by winds and surficial to mid-water currents. The increased relative abundance of palygorskite in the dark layers on the Owen Ridge suggests a strengthening of the southwest (summer) monsoon during these times. Second, the dark layers contain more organic carbon than the light layers, at least in the Miocene section (D. Murray, pers. comm., 1990), even though an unknown amount of organic carbon was metabolized to eliminate free oxygen and precipitate the associated high levels of sulfur. The increase in organic carbon content may record increased productivity during upwelling driven by more vigorous southwest monsoons, or it may reflect decreased carbon remineralization during these intervals. The latter could arise if more vigorous monsoonal circulation enhanced precipitation and runoff, thereby producing low salinity surface waters that increased density stratification and enhanced the oxygen minimum zone. Third, biosiliceous material is more abundant in the dark layers, at least in the Miocene section (D. Murray, pers. comm., 1990), and contains cold water radiolarian assemblages that can be considered as indicators of upwelling (Prell,
Niitsuma, et al., 1989). These occurrences are consistent with the interpretations of Prell (1984) and Fontugne and Duplessy (1986) that the initiation of the southwest monsoon marked the onset of upwelling along the Arabian coast.

The relative enrichment of quartz and feldspar in the dark layers is more difficult to explain with this general model, however, since the important modern sources for quartz generally lie north and east of the Owen Ridge (Kolla et al., 1981; Sirocko and Sarnthein, 1989). If such areas were also the dominant sources of quartz and feldspar in the past, then input from the north and east also must have been enhanced during intervals of a strong southwest monsoon. Bouquillon et al. (1988) hypothesize that this input is supplied by westerly and southerly flow at intermediate water depths, and that the quartz and feldspar abundances increase because the intensified southwest monsoon raises erosion rates in the continental sources. This explanation remains speculative at this time, however.

The interpretations of compositional cyclicity in the light and dark intervals presented here must be considered as working hypotheses, because preliminary results of more detailed studies 


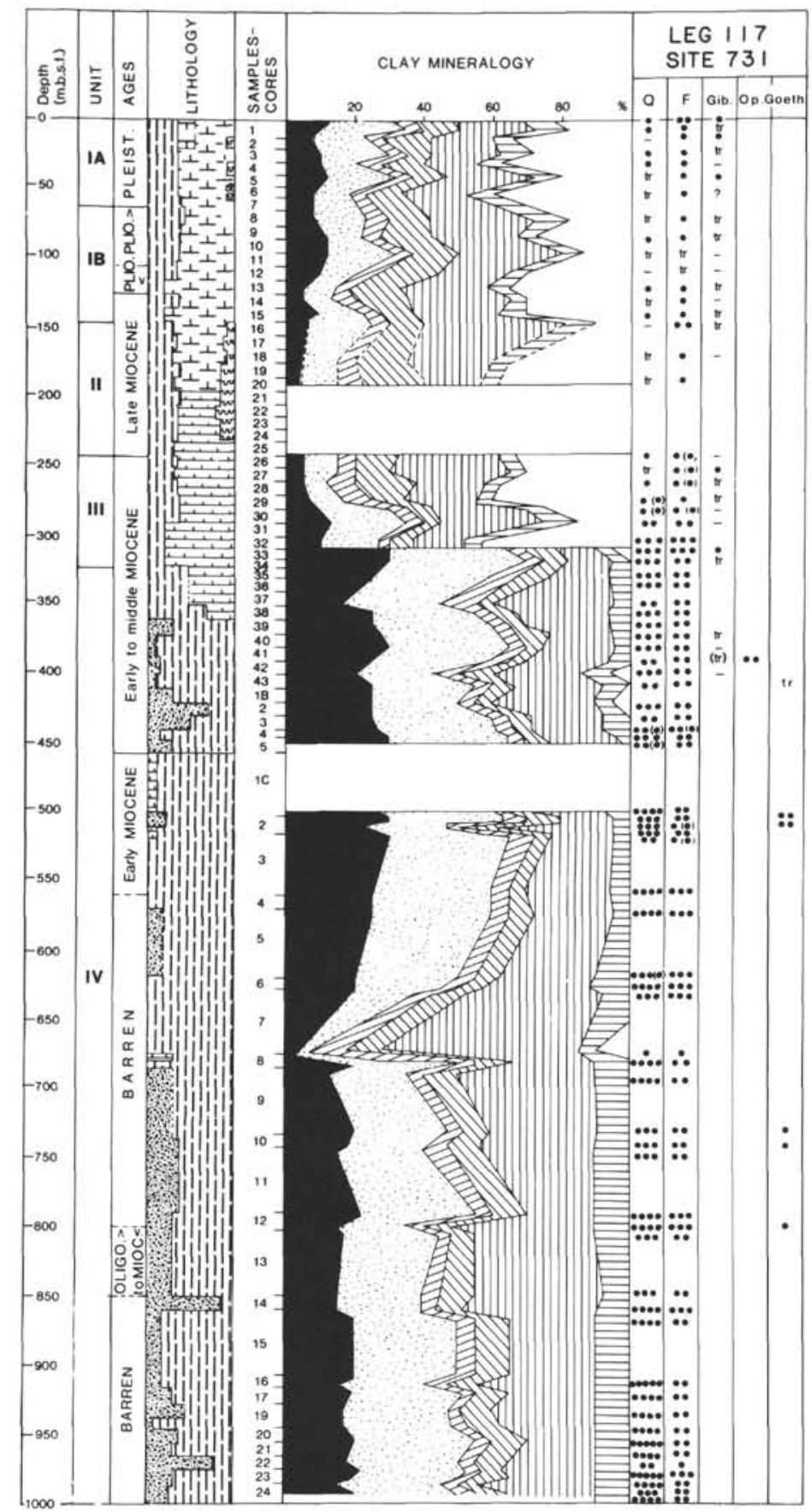

Figure 3 (continued).

indicate that the compositions of the light and dark layers change significantly through time (D. Murray, pers. comm., 1990). In particular, more detailed sampling of Pleistocene and upper Pliocene sediments has revealed that opal and carbonate abundances are higher in the light layers, but that organic carbon contents do not vary consistently with sediment color (D. Murray, pers. comm., 1990). In contrast, Miocene dark layers consistently contain more opal, more organic carbon, and less carbonate than the adjacent light layers (D. Murray, pers. comm., 1990).

\section{CLAY MINERALOGY OF OMAN MARGIN SEDIMENTS}

In order of decreasing water depth, the Oman margin sites considered here are Sites 728, 730, 723, 725, and 726 (Fig. 1). These sites span the depth of the modern oxygen minimum zone (OMZ) on this margin, and will be discussed here as lower (Sites 728 and 730), intermediate (Site 723), and upper (Sites 725 and 726) OMZ settings. Characteristics of the sedimentary sections at several of these sites (benthic foraminifer faunas, unconform- 
CLAY MINERALOGY

CHLORTE
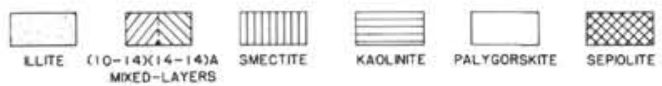

LITHOLOGY

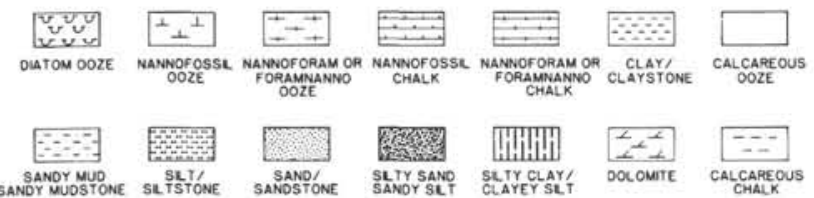

Figure 3 (continued).

ities, etc.) indicate that they have experienced significant vertical displacements during the Neogene, so their positions relative to the OMZ have changed.

\section{Lower OMZ Setting}

Sites 728 and 730 are presently located in water depths of $1427 \mathrm{~m}$ and $1066 \mathrm{~m}$, respectively, close to the base of the present OMZ (Prell, Niitsuma, et al., 1989). Site 728 was located in a deeper slope basin formed as a half-graben between adjacent blocks of ophiolitic(?) basement, and approximately $350 \mathrm{~m}$ of Holocene to upper Miocene marly calcareous ooze, marly nannofossil ooze and chalk, and nannofossil ooze and chalk were recovered at the site. Siliceous microfossils were present in low abundance $(<10 \%)$ throughout most of the recovered section. Site 730 was positioned east of the ridge of presumed ophiolitic basement that separates the upper and lower sedimentary basins in this part of the Oman margin, in order to penetrate a prominent unconformity in sediments adjacent to the basement ridge. Three lithologic units were identified in the $404 \mathrm{~m}$ of section recovered at Site 730: Unit I (0-15 mbsf) of Holocene to Pleistocene marly nannofossil ooze, which overlies the unconformity; Unit II (15-201 mbsf) of middle Miocene marly nannofossil ooze and diatomaceous silty clay; and Unit III (201-404 mbsf) of slumped, upper lower Miocene to middle Miocene foraminifer-nannofossil chalk.

Clay mineral assemblages at these two sites are shown in Figure 4 , and mean relative abundances for each lithologic unit are given in Table 2. The lower Miocene and lower middle Miocene sediments (below approximately $250 \mathrm{mbsf}$ ) are dominated by fi-

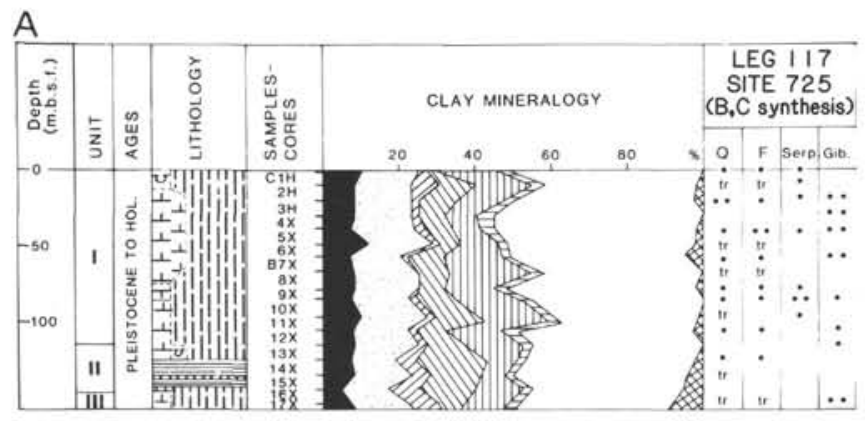

Figure 4. Clay mineral abundances at Sites $723,725,726,728$, and 730 on the Oman margin. Sites arranged in a transect from west to east in the following order: A. 725. B. 726. C. 723. D. 730. E. 728. "Q," "F," "S" or "Serp," "G" or "Gib" or "Gibb," "Z," and "Amp" columns indicate relative abundances of quartz, feldspars, serpentine, gibbsite, zeolites, and amphiboles, respectively ("tr" indicates trace amounts; more dots indicate greater relative abundance). Lithologic symbols same as in Figure 2.
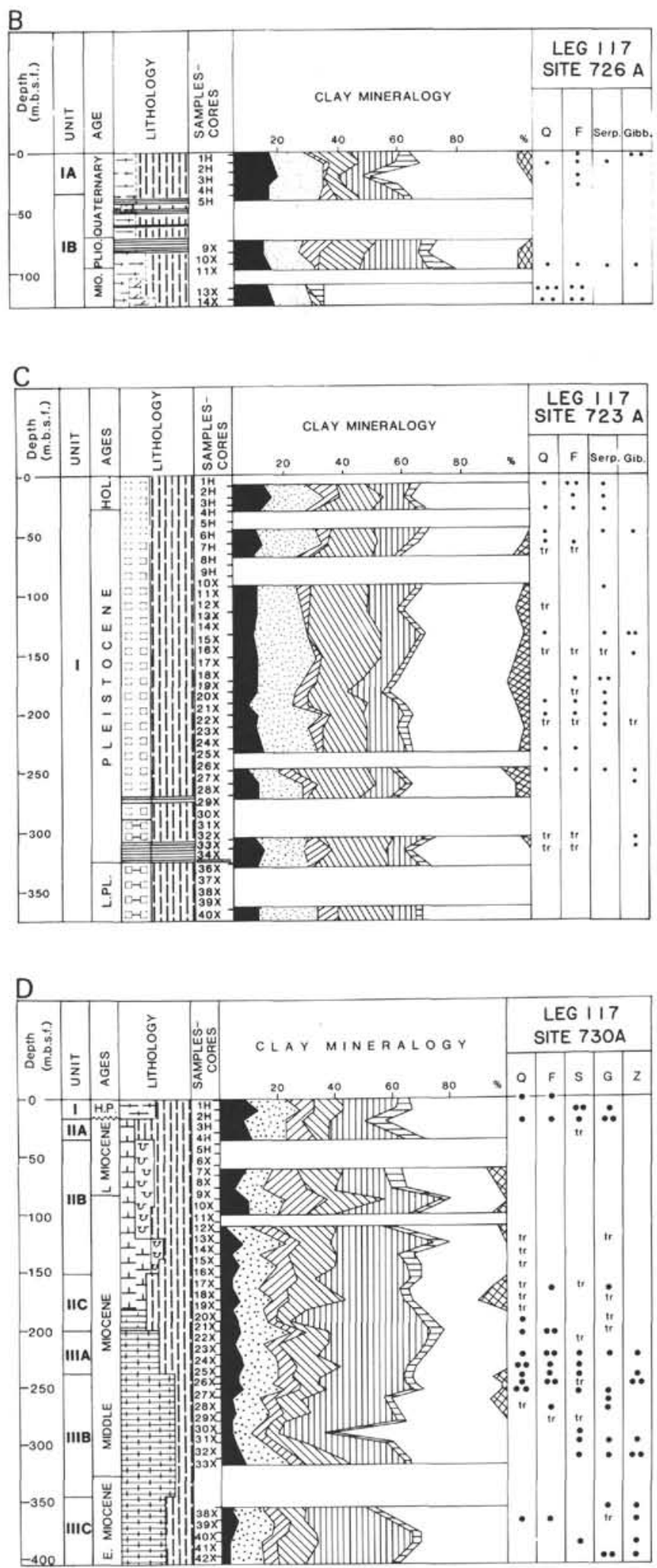

Figure 4 (continued). 


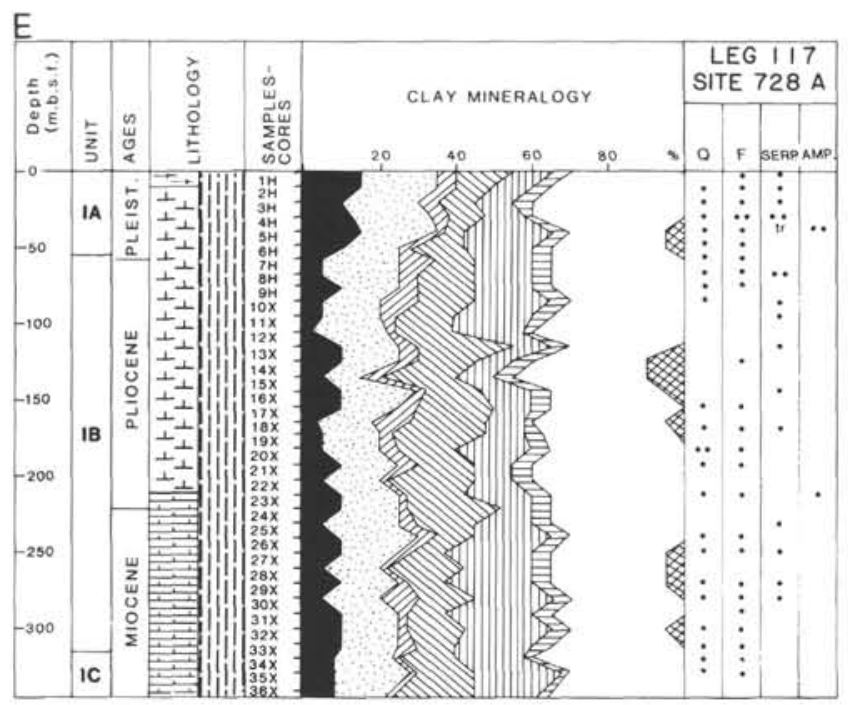

CLAY MINERALOGY

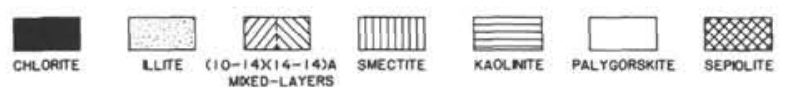

LITHOLOGY

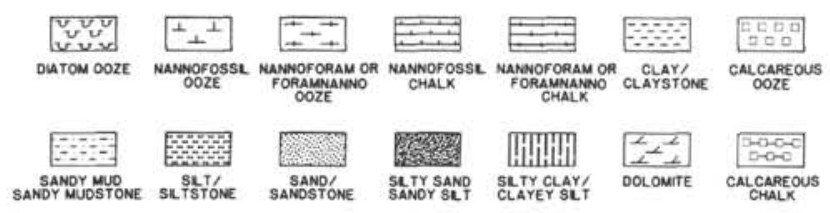

Figure 4 (continued).

brous clays $(35 \%-60 \%)$ and smectites $(25 \%-40 \%)$. Accessory minerals include illites $(10 \%-15 \%), 14-14 \AA$ mixed layer minerals $(5 \%-15 \%)$, and chlorites and $10-14 \AA$ mixed layer minerals ( $5 \%$ each). Kaolinite is present in only trace amounts. Relative abundances of the fibrous clays (palygorskite and sepiolite) are slightly lower above approximately 240 mbsf. Upper Miocene and younger sediments at Site 730 show a slight increase in the relative abundance of chlorite and illite, whereas the relative abundance of smectite decreases slightly. Palygorskite relative abundances remain approximately constant above the middle Miocene section, and no major mineralogic change occurs across the Miocene/Pleistocene hiatus at Site 730.

The Pliocene section was recovered at Site 728 , where variations in the clay mineral relative abundances are correlated to light and dark color banding in the sediments. Although the compositional variations are smaller in magnitude than those observed on the Owen Ridge, 14-14 $\AA$ mixed-layer clays become slightly more abundant and smectite relative abundances decrease upcore. Illite and chlorite relative abundances increase slightly in the Pleistocene section of Site 728 , producing a clay mineral assemblage that resembles one previously recovered from the Socotra margin (Caulet et al., 1988).

Accessory minerals are present throughout these sites. Quartz and feldspar are generally rare, and serpentine and gibbsite are common. Zeolites, especially clinoptilolite, are common in the lower and lower-middle Miocene samples.

\section{Intermediate OMZ Setting}

Site 723 is presently located in an upper slope basin on the Oman margin, in a water depth of $808 \mathrm{~m}$. Sediments recovered were grouped as one lithologic unit, with three interbedded facies. Facies I is the dominant facies, and is composed of foraminifer-bearing marly nannofossil ooze and calcareous clayey silt. Facies II consists of cemented dolomite beds and stringers, and Facies III contains centimeter-thick intervals of laminated nannofossil or diatom ooze and organic-rich clayey silt. The section is late Pliocene to Holocene in age.

Clay mineral relative abundances are shown in Figure 4 and average values are given in Table 2 . The fibrous clays form $35 \%$ $45 \%$ of the clay mineral assemblage. Sepiolite is present in all Pleistocene samples. Other minerals present include 14-14 $\AA$ mixed-layer clays $(15 \%-25 \%)$, illite $(15 \%-20 \%)$, smectite $(10 \%$ $15 \%$ ), and chlorite $(5 \%-10 \%)$. Although the sedimentation rate

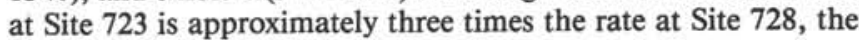
mineral assemblages at the two sites are very similar.

\section{Upper OMZ Setting}

Site 725 is presently located on the landward flank of the upper slope basin in $311 \mathrm{~m}$ of water, whereas Site 726 is presently located on an apparent pre-Neogene basement high landward of the upper slope basin in $331 \mathrm{~m}$ of water. Both sites now lie near the upper boundary of the modern OMZ. Sediments recovered at Site 725 are Pleistocene to Holocene in age, and include a lithologic Unit I ( $0-120$ mbsf) of foraminifer-rich calcitic sandy silt to calcitic marly nannofossil ooze and nannofossil-rich sand, silt, or clay; a lithologic Unit II (120-145 mbsf) of laminated diatomaceous clayey silt and calcitic marly nannofossil ooze and calcitic sand, silt, and clay; and a lithologic Unit III (145-163 mbsf) of nannofossil-rich calcitic sand, silt, and clay and calcitic marly nannofossil ooze. The section recovered at Site 726 contains a pronounced hiatus, which spans the Eocene to the late Miocene; only upper Miocene to Quaternary sediments have been analyzed for this study. The section above the hiatus at Site 726 is described as one lithologic unit, composed of nannofossil-rich calcitic silty clay to clayey silt, with intercalated lag deposits of sand-sized foraminifers, phosphatic grains, and fish teeth/bones that record the effects of current winnowing.

The upper Miocene sediments at Site 726 contain a clay mineral assemblage that is unique among the Oman margin samples in its high relative palygorskite content (approximately 70\%) and the absence of sepiolite and smectite (Fig. 4). The presence of quartz, feldspars, and dolomite is indicated by the diffractograms, and dolomite abundances of $5 \%-30 \%$ were estimated from smear slides of the bulk sediment (Prell, Niitsuma, et al., 1989). The association of palygorskite and dolomite suggests that these sediments were supplied from evaporitic environments in peri-marine and semi-enclosed basins; such basins could have been favored in the shallow-water setting indicated by the nummulitic and oncolitic limestones that underlie the Miocene sediments at Site 726 . Smectites transported from the northeast by mid-water currents would have been excluded from such shallow-water environments. Palygorskite relative abundances decrease to $25 \%-35 \%$ near the Miocene/Pliocene boundary, whereas the relative abundances of smectite and mixed-layer clays increase. The lack of appropriate samples prevents further discussion of variations within the Pliocene section.

Clay mineral assemblages in the Pleistocene sediments of both Site 725 and Site 726 are dominated by palygorskite and sepiolite, which together form $45 \%-55 \%$ of the clays. Illite and chlorite together form $25 \%-35 \%$ of the clays, whereas smectite 
and 14-14 $\AA$ mixed-layer clay relative abundances are approximately $10 \%-15 \%$ each. Smectites and mixed-layer clays are especially abundant in the Pliocene sediments of Site 726 , and mixed-layer clays are relatively abundant in the laminated Pleistocene intervals of Site 725 .

\section{Interpretations of Clay Minerals from the Oman Margin}

The general characteristics of the clay mineral assemblages present on the Oman margin and their lateral and temporal variations provide valuable evidence for the interpretation of sediment sources and dispersal patterns through time. The major observation available from our mineralogical data is the abundance of fibrous clays, especially palygorskite, on the Oman margin; the relative abundance of the fibrous clays is up to twice that of the post-lower Miocene sediments on the Owen Ridge (compare Figs. 3 and 4; Table 2). The increased relative abundance of palygorskite on the Oman margin, as well as the west-to-east increase in smectite/palygorskite ratios (Table 3), supports an interpretation of a western source as the dominant supplier of the fibrous clays to the western Arabian Sea. This pattern is also exhibited on a smaller scale in the Quaternary sediments of the Oman margin, where palygorskite and sepiolite relative abundances gradually decrease from Sites $725(47 \%)$ and $726(43 \%)$ to Site $728(35 \%)$, and the smectite/palygorskite ratio increases.

On the Owen Ridge, the most consistent change in clay mineral relative abundances is the decrease in chlorite and illite and increase in palygorskite that accompanies the lower Miocene shift from turbidite to pelagic deposition (Fig. 3). This change in depositional process, and the accompanying compositional changes, record the shift from the Himalayan source to one or several African and Arabian sources. On the Oman margin, palygorskite, smectite, and mixed-layer clay relative abundances are the most variable, but these variations all occur within hemipelagic deposits. The predominance of hemipelagic sediments and their limited range of mineralogic composition combine to suggest that these sediments were supplied from similar source areas through time. Those source regions, their rates of sediment supply, and the sediment transport pathways may have changed subtly in response to climatic, tectonic, and/or eustatic effects, however. The relatively uniform illite and chlorite abundances on the Oman margin may reflect eolian input of these clays from sources in the Iran-Makran region (Kolla et al., 1981), instead of the Indus source that supplied these minerals to the Indus Fan and Owen Ridge. Sirocko and Sarnthein (1989) have recently mapped Holocene mass accumulation rates of various eolian components in Arabian Sea sediments, and emphasize the importance of the Persian Gulf/Gulf of Oman region as a source of wind-transported illite and chlorite; surface runoff and alongshore transport cannot be eliminated as possible input processes at these shallow-water settings, however.

On the Oman margin, palygorskite relative abundances decrease from the lower Miocene (lithologic Unit IIIC) to the middle Miocene (lithologic Units IIIA, IIC, and IIB) of Site 730, in an interval dominated by redeposited sediments (turbidites and slumps). The presence of these mass movement deposits suggests that this decrease at Site 730 actually records a change in the supply of fibrous clays relative to the other clay groups at depositional centers upslope on the Arabian shelf. The lower Miocene sediments were derived from palygorskite-rich regions on the Arabian shelf, and were redeposited by gravity-driven processes at the location of Site 730 during the early Miocene. The supply of palygorskite relative to other clays at the shelf regions declined in the middle Miocene, with an associated decrease in the relative palygorskite content of the sediments redeposited at Site 730 .
Palygorskite relative abundances also decrease above the Miocene at Site 726 (approximately $100 \mathrm{mbsf}$ ). An equivalent decrease in palygorskite relative abundance is not observed in the upper Miocene sections at Sites 728 and 730, which lie offshore from Site 726. The upper Miocene decrease at Site 726 occurs just above a major hiatus, in upper Miocene biogenic and eolian upwelling deposits that overlie Eocene shallow-water limestones. In this case, the general depositional sequence and the decreasing importance of a palygorskite + dolomite assemblage suggest the subsidence and subsequent erosion of an evaporitic zone where these two minerals were formed. Palygorskite relative abundances do not exhibit a correlative decrease at the more offshore locations (Sites 728 and 730), suggesting that the supply of palygorskite relative to the other clay groups was unaffected at the offshore locations by the late Miocene climatic/ tectonic/eustatic events that changed the relative rates of supply at Site 726.

The oldest record of variations in smectite abundance is available from Site 730 , where smectite relative abundances average approximately $30 \%$ in lower and middle Miocene sediments (lithologic Units IIIC, IIIB, IIIA, and IIC; Table 2). Smectite relative abundances decrease at that site in the upper half of the middle Miocene and the upper Miocene (lithologic Units IIB and IIA), and decrease slightly through the Pliocene and Quaternary sections at other Oman margin sites. The smectite decrease is accompanied by an increase in the relative abundance of mixed-layer clays and a decrease in the smectite/kaolinite ratio (Table 3), suggesting an increase in the intensity (humidity and/or duration) of chemical weathering through time.

Within the limitations of core recovery and available samples, stratigraphic patterns of variation in clay mineral abundances on the Oman margin show consistent relationships to the bathymetric setting of the sites drilled (Fig. 4). Sites 723 and 728 were located in the slope basins on the Oman margin, and exhibit fairly regular patterns of variation in mineral abundances. Sites 726 and 730 were located on or near basement ridges and contain significant hiatuses; clay mineral abundances at these sites vary more irregularly. One possible explanation for this difference in style of variation is that bottom currents have reworked more sediment on the basement ridges than in the slope basins, thereby modifying the climatic/tectonic signal preserved by the clays at the exposed sites.

\section{CONCLUSIONS}

Clay mineral assemblages of sediments recovered from ODP Leg 117 sites on the Indus Fan, Owen Ridge, and Oman margin reveal a consistent record of sediment sources and dispersal patterns to the Arabian Sea from the Miocene to the present. This record can be summarized as follows:

1. On the Indus Fan, distinctive clay mineral assemblages distinguish intervals of turbidite and pelagic sedimentation. The turbidites are dominated by illites and chlorites, derived from the Himalayan-Tibetan mountain complexes and supplied by the Indus drainage system. Pelagic intervals contain more smectite and palygorskite than the turbidite intervals. The smectites, which probably originated from weathering in the Deccan traps, became relatively more important when turbidite influx was reduced, perhaps during eustatic sea-level highstands. The palygorskite was derived from sources to the west, and was probably transported by winds.

2. On the Owen Ridge, the oldest sediments recovered are Miocene turbidites, which are mineralogically similar to the Pleistocene turbidites sampled on the Indus Fan. These similarities in composition and depositional environment indicate that both sets of deposits were derived from similar sources, and that the turbidites on the Owen Ridge record deposition prior to ridge 
uplift. Palygorskite relative abundances increase in lower middle Miocene sediments that are more pelagic in nature; these changes are interpreted to record uplift of the ridge sites above the level of turbidity flow influence, so that eolian-supplied clays became dominant. In the middle to upper Miocene sediments, further increases in palygorskite relative abundance are accompanied by the preservation of biosiliceous components. This correlation suggests that high productivity in an upwelling zone was driven by vigorous southwest monsoons, which supplied fibrous clays from saline and alkaline environments in the deserts of east Africa and Arabia. Upper Miocene to Quaternary sediments on the Owen Ridge are dominated by macroscopic and compositional patterns of cyclicity. Detailed mineralogical and geochemical studies suggest that the darker laminations within the Miocene cycles were deposited under the influence of intensified southwest monsoons, but the relationship between monsoon intensity and Pliocene-Pleistocene sediment composition is unclear at present.

3. Clay mineral assemblages on the Oman margin contain relatively more fibrous clays and 14-14 $\AA$ mixed-layer clays and relatively less smectite than those on the Owen Ridge. The Oman margin assemblage is similar to that observed previously on the Socotra margin, supporting the interpretation of a western source for the fibrous and mixed-layer clays, and predominantly eastern and northern sources for the smectites. Appropriate source areas for the fibrous clays and the mixed-layer clays exist on the Arabian peninsula or in East Africa; the summer (southwest) monsoonal winds are available to transport these materials to the Oman margin, although runoff may be important seasonally. Additional eolian materials, especially illite, chlorite, and some smectite and kaolinite, were probably also supplied during the summer, but by northwesterly winds moving out of the Persian Gulf and the Gulf of Oman (Sirocko and Sarnthein, 1989). Local sources of the fibrous clays may have existed on the Oman margin at one time, but were destroyed by tectonic fragmentation and deepening of peri-marine evaporitic basins in the Miocene. Records of more recent climatic fluctuations have been modified by local current effects on the margin, especially on or near basement highs.

\section{ACKNOWLEDGMENTS}

We wish to acknowledge the contribution of the ship's crew and technicians to the successful operations of Leg 117. V. Kolla and M. Leinen provided thorough and helpful reviews of this contribution.

\section{REFERENCES}

Biscaye, P. E., 1965. Mineralogy and sedimentation of recent deep-sea clays in the Atlantic Ocean and adjacent seas and oceans. Geol. Soc. Am. Bull., 76:803-832.

Bouquillon, A., Debrabant, P., Nitsuma, N., Prell, W., and Shipboard Scientific Party, Leg 117, 1988. Clay mineralogy in Neogene to Quaternary sediments of the NW Indian Ocean. 69th LAS Regional Meeting Sedimentol., Leuven. (Abstract)
Caulet, J. P., Debrabant, P., and Fieux, M., 1988. Dynamique des masses d'eaux océaniques et sédimentation quaternaire sur la marge de l'Afrique de l'Est et dans le bassin de Somalie. Résultats préliminaires de la mission MD 44-INDUSOM du Marion-Dufresne. C. $R$. Acad. Sci. Ser. 2, 307:281-288.

Chamley, H., 1979. North Atlantic clay sedimentation and paleoenvironment since the Late Jurassic. In Talwani, M., Hay, W., and Ryan, W.B.F. (Eds.), Deep Drilling Results in the Atlantic Ocean: Continental Margins and Paleoenvironment: Am. Geophys. Union, Maurice Ewing Ser., 342-360. , 1989. Clay Sedimentology: New York (Springer-Verlag).

Chamley, H., and Debrabant, P., 1984. Mineralogical and geochemical investigations of sediments on the Mazagan Plateau, northwestern African margin (Leg 79, Deep Sea Drilling Project). In Hinz, K., Winterer, E. L., et al., Init. Repts. DSDP, 79: Washington (U.S. Govt. Printing Office), 497-503.

Fontugne, M. R., and Duplessy, J. C., 1986. Variations of the monsoon regime during the upper Quaternary: evidence from carbon isotopic record of organic matter in the North Indian Ocean sediment cores. Palaeogeogr., Palaeoclimatol., Palaeoecol., 56:69-88.

Gansser, A., 1966. The Indian Ocean and the Himalayas, a geological interpretation. Eclogae Geol. Helv., 59:831-848.

Griffin, J. J., Windom, H., and Goldberg, E. D., 1968. The distribution of clay minerals in the world ocean. Deep-Sea Res. Oceanogr. Abstr., 15:433-459.

Holtzapffel, T., 1985. Les minéraux argileux. Préparation-Analyse diffractométrique et détermination. Soc. Geol. Nord, 12:136.

Kolla, V., Henderson, L., Biscaye, P. E., 1976. Clay mineralogy and sedimentation in the western Indian ocean. Deep-Sea Res. Oceanogr. Abstr., 23:949-961.

Kolla, V., Kostecki, J. A., Robinson, F., Biscaye, P. E., and Ray, P. K., 1981. Distribution and origins of clay minerals and quartz in surface sediments of the Arabian Sea. J. Sediment. Petrol., 51:563-569.

Konta, J., 1985. Crystalline minerals and chemical maturity of suspended solids of some major world rivers. Mineral. Petrogr. Acta, 29A:121123.

Lisitzin, A. P., 1972. Sedimentation in the World Ocean, with Emphasis on the Nature, Distribution and Behavior of Marine Suspensions. Soc. Econ. Paleontol. Mineral Spec. Publ., 17.

Millot, G., 1964. Géologie des Argiles: Paris (Masson).

Prell, W. L., 1984. Variation of monsoonal upwelling: a response to changing solar radiation. In Hansen, J. E., and Takahashi, T. (Eds.), Climatic Processes and Climate Sensitivity. Am. Geophys. Union, Maurice Ewing Ser., 29:48-57.

Prell, W. L., Niitsuma, N., et al., 1989. Proc. ODP, Init. Repts., 117: College Station, TX (Ocean Drilling Program).

Sirocko, F., and Sarnthein, M., 1989. Wind-borne deposits in the northwest Indian Ocean: record of Holocene sediments versus modern satellite data. In Leinen, M., and Sarnthein, M. (Eds.), Paleoclimatology and Paleometeorology: Modern and Past Patterns of Global Atmospheric Transport. NATO ASI Ser., 282:401-433.

Weser, O. E., 1974. Sedimentological aspects of strata encountered on Leg 23 in the Northern Arabian Sea. In Whitmarsh, R. B., Weser, O. E., et al., Init. Repts. DSDP, 23: Washington (U.S. Govt. Printing Office), 503-519.

Date of initial receipt: 31 July 1989

Date of acceptance: 25 July 1990

Ms 117B-137 
APPENDIX

Characteristics of Light and Dark Alternations in Owen Ridge Sediments

\begin{tabular}{|c|c|c|c|c|c|c|c|c|}
\hline Sample & Age & Color & $\begin{array}{c}\mathrm{III}+\mathrm{Chl} \\
(\%)\end{array}$ & $\begin{array}{c}\text { Palyg } \\
(\%)\end{array}$ & $\begin{array}{l}C_{\text {org }} \\
(\%)\end{array}$ & $\begin{array}{c}\text { Sulfur } \\
(\%)\end{array}$ & $\begin{array}{c}\mathrm{CaCO}_{3} \\
(\%)\end{array}$ & $\mathrm{SiO}_{2} / \mathrm{Al}_{2} \mathrm{O}_{3}$ \\
\hline $721 \mathrm{~A}-3 \mathrm{H}-1,62-64 \mathrm{~cm}$ & Pleistocene & D & 25 & 30 & 0.83 & 0.152 & 61.7 & \\
\hline $721 \mathrm{~A}-3 \mathrm{H}-4,62-64 \mathrm{~cm}$ & Pleistocene & L & 30 & 25 & 0.55 & 0.252 & 60.0 & \\
\hline $721 \mathrm{~A}-4 \mathrm{H}-1,62-64 \mathrm{~cm}$ & Pleistocene & L & 25 & 25 & 0.51 & 0.202 & 81.4 & \\
\hline $721 \mathrm{~A}-4 \mathrm{H}-4,62-64 \mathrm{~cm}$ & Pleistocene & D & 15 & 35 & 0.87 & 0.258 & 65.2 & \\
\hline $721 \mathrm{~B}-11 \mathrm{X}-1,62-64 \mathrm{~cm}$ & Pliocene & D & 5 & 30 & 1.82 & 0.262 & 68.6 & \\
\hline $721 \mathrm{~B}-11 \mathrm{X}-4,62-64 \mathrm{~cm}$ & Pliocene & $\mathrm{L}$ & 5 & 25 & 0.70 & 0.245 & 80.6 & \\
\hline $721 \mathrm{~B}-12 \mathrm{X}-1,62-64 \mathrm{~cm}$ & Pliocene & D & 30 & 25 & 1.72 & 0.559 & 68.6 & \\
\hline $721 \mathrm{~B}-12 \mathrm{X}-3,10-12 \mathrm{~cm}$ & Pliocene & $\mathbf{L}$ & 25 & 20 & 0.76 & 0.256 & 79.7 & \\
\hline 721 B- $20 X-4,62-64 \mathrm{~cm}$ & $\mathrm{~m} / 1$ Miocene & L & 25 & 25 & 0.72 & 0.320 & 72.0 & \\
\hline $721 \mathrm{~B}-21 \mathrm{X}-1,62-64 \mathrm{~cm}$ & $\mathrm{~m} / 1$ Miocene & D & 20 & 30 & 2.32 & 0.644 & 46.3 & \\
\hline $721 \mathrm{~B}-22 \mathrm{X}-4,62-64 \mathrm{~cm}$ & $\mathrm{~m} / 1$ Miocene & D & 25 & 25 & 1.12 & 0.539 & 62.6 & \\
\hline $721 \mathrm{~B}-23 \mathrm{X}-1,62-64 \mathrm{~cm}$ & $\mathrm{~m} / 1$ Miocene & L & 30 & 15 & 0.60 & 0.374 & 91.8 & \\
\hline $721 \mathrm{~B}-25 \mathrm{X}-1,70-72 \mathrm{~cm}$ & $\mathrm{~m} / 1$ Miocene & D & 15 & 25 & 1.32 & 0.537 & 64.3 & \\
\hline $721 \mathrm{~B}-25 \mathrm{X}-4,62-64 \mathrm{~cm}$ & $\mathrm{~m} / \mathrm{l}$ Miocene & $\mathrm{L}$ & 25 & 20 & 0.40 & 0.256 & 80.6 & \\
\hline $721 \mathrm{~B}-30 \mathrm{X}-1,62-64 \mathrm{~cm}$ & $\mathrm{~m} / 1$ Miocene & $\mathrm{L}$ & 20 & 20 & 0.33 & 0.271 & 65.2 & \\
\hline $721 \mathrm{~B}-31 \mathrm{X}-1,62-64 \mathrm{~cm}$ & $\mathrm{~m} / \mathrm{I}$ Miocene & D & 15 & 25 & 0.62 & 0.363 & 43.7 & \\
\hline $721 B-33 X-1,62-64 \mathrm{~cm}$ & e Miocene & D & 15 & 30 & 1.46 & 0.916 & 28.6 & \\
\hline $721 \mathrm{~B}-34 \mathrm{X}-1,60-62 \mathrm{~cm}$ & e Miocene & $\mathrm{L}$ & 20 & 25 & 0.10 & 0.005 & 88.3 & \\
\hline $722 \mathrm{~A}-3 \mathrm{H}-1,95-97 \mathrm{~cm}$ & Pleistocene & L & 35 & 15 & 0.37 & 0.162 & 66.9 & 4.36 \\
\hline $722 \mathrm{~A}-4 \mathrm{H}-1,95-97 \mathrm{~cm}$ & Pleistocene & D & 35 & 20 & 1.34 & 0.285 & 51.4 & 4.61 \\
\hline $722 \mathrm{~A}-10 \mathrm{X}-1,95-97 \mathrm{~cm}$ & Pliocene & D & 20 & 20 & 2.87 & 0.689 & 58.3 & 4.83 \\
\hline $722 \mathrm{~A}-11 \mathrm{X}-1,95-97 \mathrm{~cm}$ & Pliocene & L & 30 & 10 & 0.92 & 0.294 & 73.7 & 4.50 \\
\hline $722 \mathrm{~A}-15 \mathrm{X}-1,95-97 \mathrm{~cm}$ & Pliocene & L & 35 & 15 & 0.96 & 0.286 & 80.6 & 4.37 \\
\hline $722 \mathrm{~A}-16 \mathrm{X}-1,95-97 \mathrm{~cm}$ & Pliocene & D & 20 & 25 & 2.50 & 0.568 & 66.0 & 5.00 \\
\hline $722 \mathrm{~A}-20 \mathrm{X}-1,95-97 \mathrm{~cm}$ & 1 Miocene & D & 25 & 20 & 0.92 & 0.390 & 70.3 & 4.66 \\
\hline $722 \mathrm{~A}-21 \mathrm{X}-1,95-97 \mathrm{~cm}$ & 1 Miocene & $\mathrm{L}$ & 30 & 10 & 0.29 & 0.158 & 84.0 & 4.69 \\
\hline $722 \mathrm{~B}-30 \mathrm{X}-1,95-97 \mathrm{~cm}$ & 1 Miocene & $\mathrm{L}$ & 30 & 15 & 0.32 & 0.160 & 84.0 & 5.69 \\
\hline $722 \mathrm{~B}-31 \mathrm{X}-1,95-97 \mathrm{~cm}$ & 1 Miocene & D & 20 & 25 & 1.06 & 0.489 & 38.6 & 6.38 \\
\hline $722 \mathrm{~B}-36 \mathrm{X}-1,95-97 \mathrm{~cm}$ & m Miocene & D & 20 & 25 & 0.74 & 0.355 & 26.6 & 7.28 \\
\hline $722 \mathrm{~B}-37 \mathrm{X}-1,94-96 \mathrm{~cm}$ & m Miocene & $\mathrm{L}$ & 29 & 15 & 0.20 & 0.535 & 80.6 & 5.52 \\
\hline \multicolumn{2}{|c|}{ Light layer mean } & & 28 & 19 & 0.56 & 0.252 & 78.0 & 4.86 \\
\hline \multicolumn{2}{|c|}{ Dark layer mean } & & 22 & 26 & 1.47 & 0.466 & 54.6 & 5.46 \\
\hline
\end{tabular}

Note: Ill $=$ illite Chl $=$ chlorite Palyg $=$ palygorskite $; \mathrm{C}_{\text {org }}=$ organic carbon . 

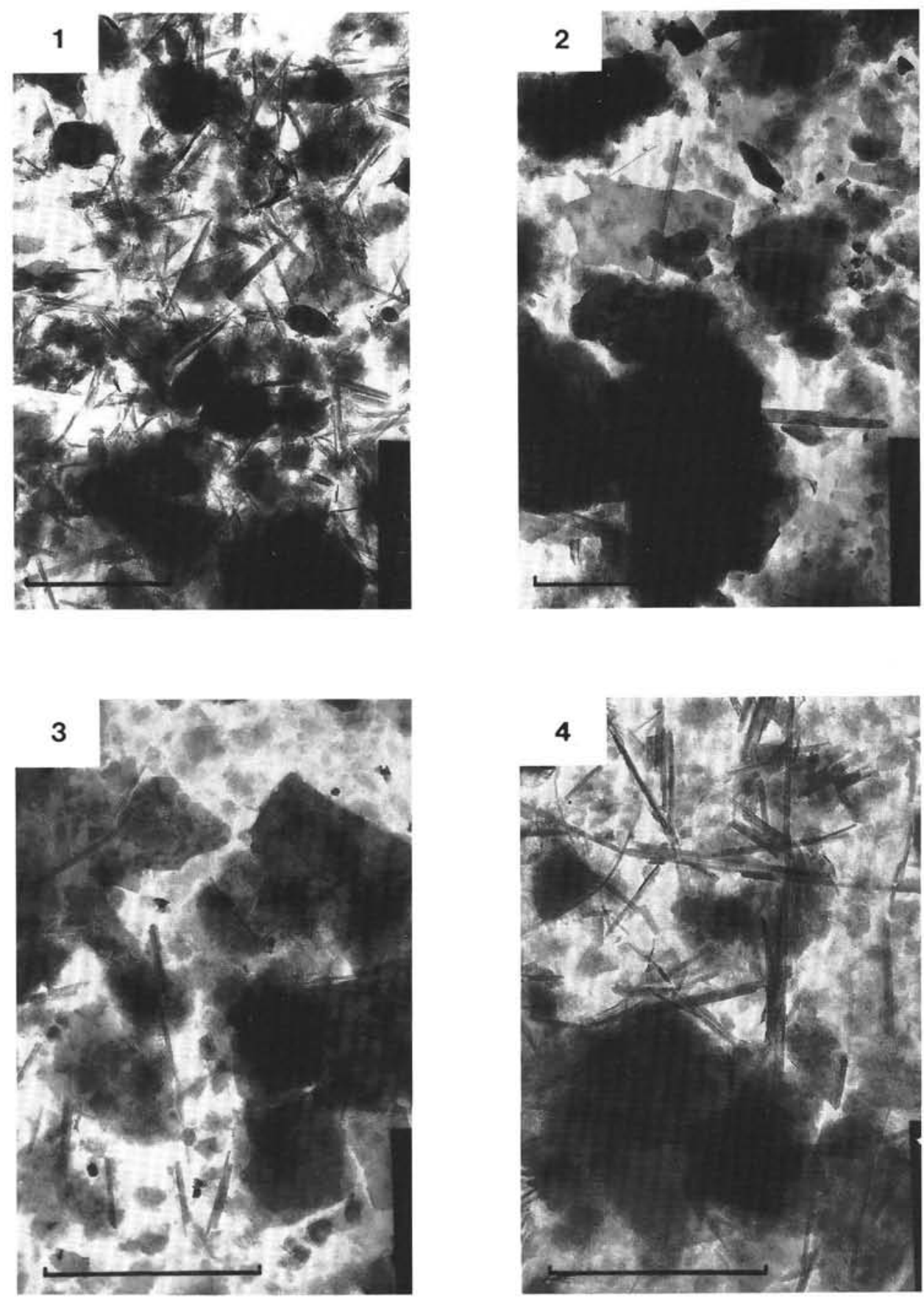

Plate 1. Transmission electronmicrographs of the clay-sized fraction in samples from the Indus Fan and the Owen Ridge. Bar scale is $1 \mu \mathrm{m}$ in each case. 1. Sample $720-30 X-5,61 \mathrm{~cm}$. Pleistocene pelagic sediment from the Indus Fan, containing abundant broken palygorskite fibers. 2. Sample $720-31 X-1,58 \mathrm{~cm}$. Pleistocene turbidite from the Indus Fan, containing abundant illite and chlorite particles and very few palygorskite fibers. 3. Sample $722-44 \mathrm{X}-1,96 \mathrm{~cm}$. Lower middle Miocene turbidite from the Owen Ridge, containing abundant illite and chlorite. 4. Sample 722-41X-1, $94 \mathrm{~cm}$. Lower middle Miocene pelagic sediment from the Owen Ridge, containing abundant palygorskite fibers. 